\title{
Hormigón alternativo basado en escorias activadas alcalinamente
}

\section{Alternative concrete based on alkali-activated slag}

\author{
E. Rodríguez ${ }^{(*)}$, S. Bernal(*), R. Mejía de Gutiérrez ${ }^{(*)}$ y F. Puertas ${ }^{(* *)}$
}

Recepción/Received: 10-V-07

Aceptación/Accepted: 25-X-07

Publicado online/Online publishing: 28-V-08

\section{RESUMEN}

El propósito de este artículo es dar a conocer los resultados de la evaluación del comportamiento de mezclas de hormigón producidas a partir de la activación con waterglass $\left(\mathrm{Na}_{2} \mathrm{SiO}_{3} \cdot \mathrm{nH}_{2} \mathrm{O}+\mathrm{NaOH}\right)$ de una escoria siderúrgica granulada de alto horno colombiana. Las propiedades mecánicas y de durabilidad de los hormigones activados alcalinamente (AAS) se comparan con las correspondientes mezclas de hormigón de cemento Portland (OPC) producidas con igual proporción de ligante. Estas proporciones variaron entre 340 y $512 \mathrm{~kg}$ por $\mathrm{m}^{3}$ de hormigón. Los resultados obtenidos indican que incrementos en la proporción de la escoria contribuye a la mejora de las propiedades evaluadas.

Palabras clave: escoria granulada de alto horno, hormigón de escoria activada, durabilidad.

\section{SUMMARY}

This article reports the results of related to on the performance of concrete made with waterglass $\left(\mathrm{Na}_{2} \mathrm{SiO}_{3} \cdot \mathrm{nH}_{2} \mathrm{O}\right.$ $+\mathrm{NaOH}$ )-activated Colombian granulated blast furnace slag. The mechanical strength and durability properties this alkali-activated slag concrete (AAS) were compared to the properties of ordinary Portland cement concrete (OPC) with the same proportion of binder, which ranged from 340 to $512 \mathrm{~kg}$ per $\mathrm{m}^{3}$ of concrete. The results indicated that increasing the proportion of slag led to improvements in the properties studied.

Keywords: granulated blast furnace slag, alkali-activated slag concrete, durability.

\section{INTRODUCCIÓN}

Grandes volúmenes de residuos sólidos son producidos anualmente por diversos sectores de la industria, convirtiéndose en un problema medio ambiental debido a las dificultades en su almacenamiento y disposición. Es por

\section{INTRODUCTION}

The large volumes of industrial solid waste produced yearly generate storage and disposal problems with a substantial environmental impact. This situation has led to the institution of international policies and agreements

\footnotetext{
(*) Universidad del Valle, Cali (Colombia).

(**) Instituto de Ciencias de la Construcción Eduardo Torroja, (CSIC) (Madrid, España).
} 
ello que se han planteado políticas y acuerdos internacionales, como el convenio de Viena sobre la Protección de la Capa de Ozono (1985), el protocolo de Montreal (1987), de Kyoto (1997) y la Cumbre de Johannesburgo (2002), que buscan el desarrollo tecnológico a través del aprovechamiento de los recursos no renovables, con la disminución en el consumo de energía, de la producción de residuos y la emisión de gases contaminantes.

La producción mundial de cemento Portland, el cual es usado convencionalmente como el ligante primario para la elaboración de hormigón, en los últimos años fue cerca de 1,8 billones de toneladas (1) con un consumo aproximado de 3 billones de toneladas de recursos naturales por año como materia prima (caliza y arcilla), además de un consumo apreciable de energía (3.530kJ/kg de cemento) y de combustibles fósiles. Cabe anotar, que en el proceso de fabricación de una tonelada de cemento se libera alrededor de una tonelada de $\mathrm{CO}_{2}$ a la atmósfera, además de emisiones de $\mathrm{SO}_{\mathrm{x}}$ y $\mathrm{NO}_{\mathrm{x}}$. Por ello, la producción del cemento es considerada la responsable de aproximadamente un $5 \%$ de la emisión de $\mathrm{CO}_{2}$ antropogénico global a nivel mundial (2).

En la búsqueda de soluciones, investigadores a nivel mundial evalúan el empleo de materiales alternativos o desechos sólidos para la conservación de recursos y disminución del consumo de energía en la fabricación del cemento y hormigón, teniendo en cuenta las ventajas tecnológicas y la compatibilidad ambiental. Los subproductos tales como la ceniza volante, el humo de sílice y las escorias siderúrgicas se han empleado con éxito como un substituto parcial de cemento Portland ordinario (OPC), contribuyendo así a la mejora de las propiedades físico mecánicas y de durabilidad en relación a los materiales tradicionales. Debido a la hidraulicidad latente que presenta la escoria siderúrgica granulada de alto horno este producto ha sido empleado como un sustituto parcial del cemento Portland, con ventajas tales como una mayor durabilidad y bajos calores de hidratación comparados con muestras producidas con un $100 \%$ de OPC; sin embargo, la cantidad de material a sustituir se ha visto limitado debido al lento desarrollo resistente de cementos con altos contenidos de escoria. Como alternativa se ha implementado la activación alcalina de la escoria, originando materiales que carecen totalmente de cemento Portland, a través de la incorporación de bases fuertes que favorecen la disolución de la misma y aceleran los mecanismos de endurecimiento permitiendo con ello la obtención de elevadas resistencias. El estudio de estos materiales se remonta a la década de los sesenta en la Unión Soviética, Escandinavia y el este de Europa (3).

En general, los cementos activados alcalinamente consisten en un sistema que emplea un activador alcalino el cual promueve una o varias reacciones sobre un sólido inorgánico de origen natural o artificial que da lugar a un such as the Vienna Convention for the Protection of the Ozone Layer (1985), the Montreal Protocol (1987), the Kyoto Agreement (1997) and the Johannesburg Summit (2002), that seek technological developments able to provide for the rational use of non-renewable resources and reduce energy consumption, waste generation and the emission of polluting gas.

Portland cement is the binder conventionally used to produce concrete. World-wide production in recent years, which came to nearly 1.8 billion tonnes (1), entailed the consumption of approximately 3 billion tonnes of natural raw materials (limestone and clay), along with substantial amounts of energy (3,530 kJ/kg cement) and fossil fuel. Moreover, for each tonne of cement manufactured, around one tonne of $\mathrm{CO}_{2}$ is released into the air, in addition to $\mathrm{SO}_{x}$ and $\mathrm{NO}_{x}$. Cement production is therefore regarded to account for approximately $5 \%$ of all anthropogenic $\mathrm{CO}_{2}$ emissions world-wide (2).

In their search for solutions, scientists the world over are exploring the use of alternative materials or solid waste to conserve resources and reduce energy consumption in cement and concrete manufacture, bearing in mind technological developments and environmental compatibility. By-products such as fly ash, silica fume and blast furnace slag have been successfully used as a partial substitute for ordinary Portland cement (OPC), contributing to the improvement in the physical and mechanical properties as well as the durability of traditional materials. Given the latent hydraulicity of blast furnace slag, this product has been used as a partial substitute for ordinary Portland cement in concrete production, with advantages such as longer durability and lower heat of hydration than recorded for $100 \%$ OPC samples. However, the amount of material that can be replaced has been limited by slow strength development in cements with a high slag content. One alternative is the alkali activation of the slag, which gives rise to materials totally lacking in Portland cement. This process entails the use of strong bases that favour slag dissolution and accelerate hardening mechanisms, resulting in high strength development. The study of such materials dates back to the nineteen sixties in the Soviet Union, Scandinavia and Eastern Europe (3).

In general terms, an alkali-activated cement is a system in which an alkaline activator promotes one or several reactions on an inorganic solid of natural or artificial origen that generates a material with cementitious charac- 
material con características cementantes. Un material de este tipo es el cemento de escoria activado alcalinamente (AAS), producido a partir de la mezcla de escoria granulada de alto horno con disoluciones alcalinas, cuyas propiedades y características de fluidez, durabilidad y resistencia están afectadas por factores tales como: el tipo de activador alcalino, la concentración del activador adicionado, el módulo de la solución $\left(\mathrm{Ms}=\mathrm{SiO}_{2} / \mathrm{Na}_{2} \mathrm{O}\right)$, el tipo y finura de la escoria, las condiciones de curado, la relación agua/ligante, la relación solución activante/escoria y el uso de aditivos y fibras(4-10). Particularmente, la naturaleza del activador alcalino induce diferentes estructuras y composición de los productos de hidratación. Cuando se emplea una disolución de waterglass $\left(\mathrm{Na}_{2} \mathrm{SiO}_{3} \cdot \mathrm{nH}_{2} \mathrm{O}+\right.$ $\mathrm{NaOH}$ ) los productos de hidratación formados presentan un bajo orden estructural, una baja relación $\mathrm{Ca} / \mathrm{Si}$ y presencia de unidades de $\mathrm{Si}$ en el gel de C-S-H de tipo $\mathrm{Q}^{3}$ (11).

El presente artículo es parte de un proyecto que tiene el objetivo de exponer nuevas perspectivas para la conservación de energía mediante la aplicación de nuevas tecnologías en la industria de la construcción a través de la valoración y aprovechamiento de residuos sólidos que puedan ser empleados como materiales cementicios después de ser activados alcalinamente y de esta manera contribuir con el desarrollo sostenible. En este trabajo se presenta la evaluación del comportamiento mecánico y de durabilidad de hormigones activados alcalinamente utilizando como único ligante, escoria siderurgica granulada de alto horno, en proporciones entre 340 y $512 \mathrm{Kg}$ por metro cúbico de hormigón. El comportamiento de estos materiales fue comparado frente a mezclas de hormigón producido con cemento Portland ordinario (OPC) con proporciones equivalentes.

\section{PARTE EXPERIMENTAL}

\subsection{Materiales}

Se empleó una escoria siderúrgica granulada de alto horno previamente molida de la empresa colombiana Acerias Paz del Río, la cual presentó una superficie específica de $398 \mathrm{~m}^{2} / \mathrm{Kg}$ y un peso específico de $2860 \mathrm{~kg} / \mathrm{m}^{3}$. De acuerdo a su composición química, listada en la Tabla 1 , los índices de basicidad $\left(\mathrm{Mb}=\mathrm{CaO}+\mathrm{MgO} / \mathrm{SiO}_{2}+\mathrm{Al}_{2} \mathrm{O}_{3}\right)$ y de calidad $\left(\mathrm{CaO}+\mathrm{MgO}+\mathrm{Al}_{2} \mathrm{O}_{3} / \mathrm{SiO}_{2}+\mathrm{TiO}_{2}\right)$ fueron de 1,01 y de 1,92 , respectivamente. Con referencia a la norma ASTM C989 la escoria es de grado 80. Como disolución activadora se empleó waterglass, constituida por la mezcla de un silicato de sodio comercial con un $31.70 \%$ de $\mathrm{SiO}_{2}, 12,32 \%$ de $\mathrm{Na}_{2} \mathrm{O}$ y $56,9 \%$ de agua con una disolución de $\mathrm{NaOH}$ al $50 \%$ para la obtención de un modulo de $\mathrm{SiO}_{2} / \mathrm{Na}_{2} \mathrm{O}$ de 1,3 . Como material de referencia se empleó un cemento Portland comercial (OPC) cuya composición química se muestra en la Tabla 1; este posee un conteni- teristics. One such material is alkali-activated slag (AAS) cement, which results of mixing granulated blast furnace slag and alkaline substances; its properties and workability, durability and strength are affected by factors such as: type and concentration of the alkaline activator, solution ratio $\left(\mathrm{Ms}=\mathrm{SiO}_{2} / \mathrm{Na}_{2} \mathrm{O}\right)$, slag type and fineness, curing conditions, water/cementitious material ratio, activating solution/slag ratio and the use of admixtures and fibres (4-10). In particular, the nature of the alkaline activator induces different hydration product structures and compositions. When waterglass $\left(\mathrm{Na}_{2} \mathrm{SiO}_{3} \cdot \mathrm{nH}_{2} \mathrm{O}+\mathrm{NaOH}\right)$ is used, the hydration products formed exhibit short-range structural order, a low Ca/Si ratio and the presence of $Q^{3}$ type Si units in the C-S-H gel (11).

The present article forms part of a project that aims to contribute to sustainable development by furnishing new perspectives for energy conservation through the application of innovative technologies such as alkali activation to convert solid waste into cementitious materials for the construction industry. The present paper discusses the mechanical performance and durability of alkali-activated concretes in which the sole binder is granulated blast furnace slag in proportions of from 340 to $512 \mathrm{~kg}$ per cubic metre of concrete. The performance of these materials was compared to the behaviour of concrete made with ordinary Portland cement (OPC) in equivalent proportions.

\section{EXPERIMENTAL PART}

\subsection{Materials}

The ground granulated blast furnace slag (from the Colombian company Acerías Paz del Río) used in this study had a specific surface of $398 \mathrm{~m}^{2} / \mathrm{kg}$ and a specific gravity of $2860 \mathrm{~kg} / \mathrm{m}^{3}$. Pursuant to the chemical composition listed in Table 1 , its basicity $\left(\mathrm{Mb}=\mathrm{CaO}+\mathrm{MgO} / \mathrm{SiO}_{2}+\mathrm{Al}_{2} \mathrm{O}_{3}\right)$ and quality $\left(\mathrm{CaO}+\mathrm{MgO}+\mathrm{Al}_{2} \mathrm{O}_{3} / \mathrm{SiO}_{2}+\mathrm{TiO}_{2}\right)$ indices were 1.01 and 1.92, respectively. According to ASTM standard C989 this material was grade 80 slag. The waterglass used as the activating solution consisted in a mix of commercial sodium silicate $\left(31.70 \% \mathrm{SiO}_{2}, 12.32 \% \mathrm{Na}_{2} \mathrm{O}\right.$ and $56.9 \%$ water) with a $50 \% \mathrm{NaOH}$ solution to obtain a $\mathrm{SiO}_{2} / \mathrm{Na}_{2} \mathrm{O}$ ratio of 1.3. Commercial Portland cement (OPC) was used as the control material. According to the chemical composition given in Table 1 , it contains $25 \%$ of limestone. Its specific gravity and specific surface were $2.990 \mathrm{~kg} / \mathrm{m}^{3}$, and $476 \mathrm{~m}^{2} / \mathrm{kg}$, respectively. The aggrega- 
do de adición caliza del orden del $25 \%$, un peso específico de $2990 \mathrm{~kg} / \mathrm{m}^{3}$, así como una superficie específica de $476 \mathrm{~m}^{2} / \mathrm{Kg}$. Los áridos empleados corresponden a una arena de río con una gravedad especifica de $2.450 \mathrm{~kg} / \mathrm{m}^{3}$ y módulo de finura de 2,57 y una grava de tipo silíceo con tamaño máximo de $19 \mathrm{~mm}$, gravedad especifica de 2790 $\mathrm{kg} / \mathrm{m}^{3}$ y absorción de 1,23\%. La granulometría de estos materiales se presenta en la Tabla 2. te used was river sand with a specific gravity of 2450 $\mathrm{kg} / \mathrm{m}^{3}$ and a fineness modulus of 2.57, and siliceous gravel with a maximum grain size of $19 \mathrm{~mm}$, specific gravity of $2790 \mathrm{~kg} / \mathrm{m}^{3}$ and $1.23 \%$ absorption. The size distribution of these materials is shown in Table 2.

Tabla 1 / Table 1

Composición química de la escoria y el cemento Portland Chemical Composition of Slag and Ordinary Portland Cement

\begin{tabular}{|c|c|c|}
\hline Componente / Component, \% & Escoria / Slag & Cemento / Cement \\
\hline Perdida al fuego / L.O.I. & 2.08 & 5.80 \\
\hline $\mathrm{SiO}_{2}$ & 31.08 & 20.35 \\
\hline $\mathrm{Al}_{2} \mathrm{O}_{3}$ & 13.98 & 6.06 \\
\hline $\mathrm{Fe}_{2} \mathrm{O}_{3}$ & 3.09 & 4.58 \\
\hline $\mathrm{CaO}$ & 43.92 & 57.06 \\
\hline $\mathrm{MgO}$ & 1.79 & 3.10 \\
\hline $\mathrm{SO}_{3}$ & 0.66 & - \\
\hline
\end{tabular}

Tabla 2 / Table 2

Distribución Granulométrica de los áridos Particle size distribution of aggregates

\begin{tabular}{|c|c|c|}
\hline \multirow{2}{*}{$\begin{array}{c}\text { Tamiz / } \\
\text { Sieve Size (No) }\end{array}$} & $\begin{array}{c}\text { Árido Grueso / } \\
\text { Coarse aggregate }\end{array}$ & $\begin{array}{c}\text { Árido Fino / } \\
\text { Fine aggregate }\end{array}$ \\
\cline { 2 - 3 } & $\begin{array}{c}\text { Acumulado (\%) / } \\
\text { Cumulative amount passing \% }\end{array}$ & $\begin{array}{c}\text { Acumulado (\%) / } \\
\text { Cumulative amount passing \% }\end{array}$ \\
\hline $25 \mathrm{~mm}(1 \mathrm{in})$ & 99.48 & - \\
\hline $19 \mathrm{~mm}(3 / 4 \mathrm{in})$ & 90.15 & - \\
\hline $12.5 \mathrm{~mm}(1 / 2 \mathrm{in})$ & 43.33 & - \\
\hline $9.5 \mathrm{~mm}(3 / 8 \mathrm{in})$ & 13.99 & - \\
\hline $4.75 \mathrm{~mm}(4)$ & 2.73 & 95.71 \\
\hline $2.36 \mathrm{~mm}(8)$ & - & 91.62 \\
\hline $1.18 \mathrm{~mm}(16)$ & - & 78.31 \\
\hline $600 \mu \mathrm{m}(30)$ & - & 57.60 \\
\hline $300 \mu \mathrm{m} \mathrm{(50)}$ & - & 16.83 \\
\hline $150 \mu \mathrm{m}(100)$ & - & 3.12 \\
\hline
\end{tabular}

\subsection{Diseño de las mezclas y preparación de los especímenes}

Los diseños de los hormigones de cemento Portland (OPC) y los de escoria activados alcalinamente (AAS) se realizaron de acuerdo a lo especificado en la norma ACI 211. Las cantidades de cemento o escoria por metro cúbico de hormigón fueron de 340, 410 y 512 kg (ver Tabla 3). La disolución activante de waterglass fue incorporada en las mezclas de hormigón en una concentración

\subsection{Mix design and specimen preparation}

The Portland cement (OPC) and alkali-activated slag (AAS) concretes were designed based on the ACI standard 211. Three doses of cement or slag were used to prepare the concrete mixes: 340, 410 and $512 \mathrm{~kg}$ (see Table 3) per cubic metre of concrete. The $\mathrm{Na}_{2} \mathrm{O}$ concentration in the waterglass activating solution added to the concrete mixes was $4 \%$ by slag weight. A total of five 
del $4 \%$ de $\mathrm{Na}_{2} \mathrm{O}$, expresado como porcentaje en peso de escoria. En total se prepararon 5 mezclas donde la relación agua/cemento y (agua + disoluciones activantes) /escoria fue de 0,48 , logrando así un asentamiento entre 75 y $100 \mathrm{~mm}$. La proporción de áridos finos y gruesos fue de $45 \%$ y $55 \%$ respectivamente. En ningún caso se incorporaron aditivos a las mezclas. mixes were prepared, with a water/cement and (water + activating solutions)/slag ratio of 0.48 with which was possible to obtain a slump between 75 and $100 \mathrm{~mm}$. The proportions of fine and coarse aggregate were $45 \%$ and $55 \%$, respectively. No admixtures were used in any of the mixes.

Tabla 3 / Table 3

Mezclas preparadas

Mix Code

\begin{tabular}{|c|c|}
\hline $\begin{array}{c}\text { Mezcla } \\
\text { Mix }\end{array}$ & $\begin{array}{c}\text { Cantidad de ligante por } \mathbf{~ m}^{\mathbf{3}} \text { de hormigón } \\
\text { Binder Quantity per } \mathbf{m}^{\mathbf{3}} \text { of concrete } \\
(\mathrm{Kg})\end{array}$ \\
\hline OPCC1 & 340 \\
\hline OPCC2 & 410 \\
\hline AASC1 & 340 \\
\hline AASC2 & 410 \\
\hline AASC3 & 512 \\
\hline
\end{tabular}

Para los ensayos de resistencia a compresión (ASTM C39), Absorción y porosidad total de hormigón endurecido (ASTM C642), succión capilar mediante la metodología planteada por Fagerlund (12), permeabilidad al ion cloruro (ASTM C1202) y susceptibilidad a la carbonatación se elaboraron cilindros de 76,2 mm de diámetro. La valoración del comportamiento en presencia de sulfatos (ASTM C1012) se realizó mediante probetas de 38x38×297 $\mathrm{mm}$ para monitorizar su expansión y cubos de $50 \mathrm{~mm}$ para evaluar la pérdida de resistencia.

Los hormigones de OPC cemento portland se curaron a una humedad relativa del $100 \%$, mientras que los AAS fueron curados al 90\% de H.R., para evitar lixiviación de las disoluciones activantes y no afectar los procesos de reacción y formación de los productos de reacción.

\section{RESULTADOS Y DISCUSIÓN}

\subsection{Resistencia a compresión}

La resistencia a compresión se determinó a edades de curado de 14, 28, 60 y 120 días. Los resultados obtenidos se muestran en la Figura 1. En la Tabla 4 se muestra comportamiento mecánico de los hormigones activados alcalinamente frente a los hormigones de OPC mediante la diferencia entre sus resistencias a compresión y posterior relación con la resistencia del hormigón de referencia, tal como se expresa en la Ecuación [1].
Cylindrical specimens $76.2 \mathrm{~mm}$ in diameter were made to test the materials for compressive strength (ASTM C39), absorption and voids in hardened concrete (ASTM C642), Fagerlund capillarity (12), chloride permeability (ASTM C1202) and carbonation resistance. Performance when exposed to sulphates (ASTM C1012) was tested on $38 \times 38 \times 297-\mathrm{mm}$ prisms to monitor expansion and $50-\mathrm{mm}$ cubes to assess strength loss.

The OPCC specimens were cured at a relative humidity of $100 \%$ and the AAS samples at $90 \% \mathrm{RH}$ to prevent leaching of the activating solutions and to assure that the hydration reaction and product formation processes were not affected.

\section{RESULTS AND DISCUSSION}

\subsection{Compressive strength}

The 14-, 28-, 60- and 120-day compressive strength results are shown in Figure 1. Table 4 compares the mechanical performance of alkali-activated concrete to OPCC, expressed as the ratio between the difference in their respective compressive strength values to the compressive strength of the control, in accordance with equation [1] below:

$$
I_{\text {desempeño }}=\frac{R c_{A A S}-R c_{O P C}}{R c_{O P C}} \times 100
$$




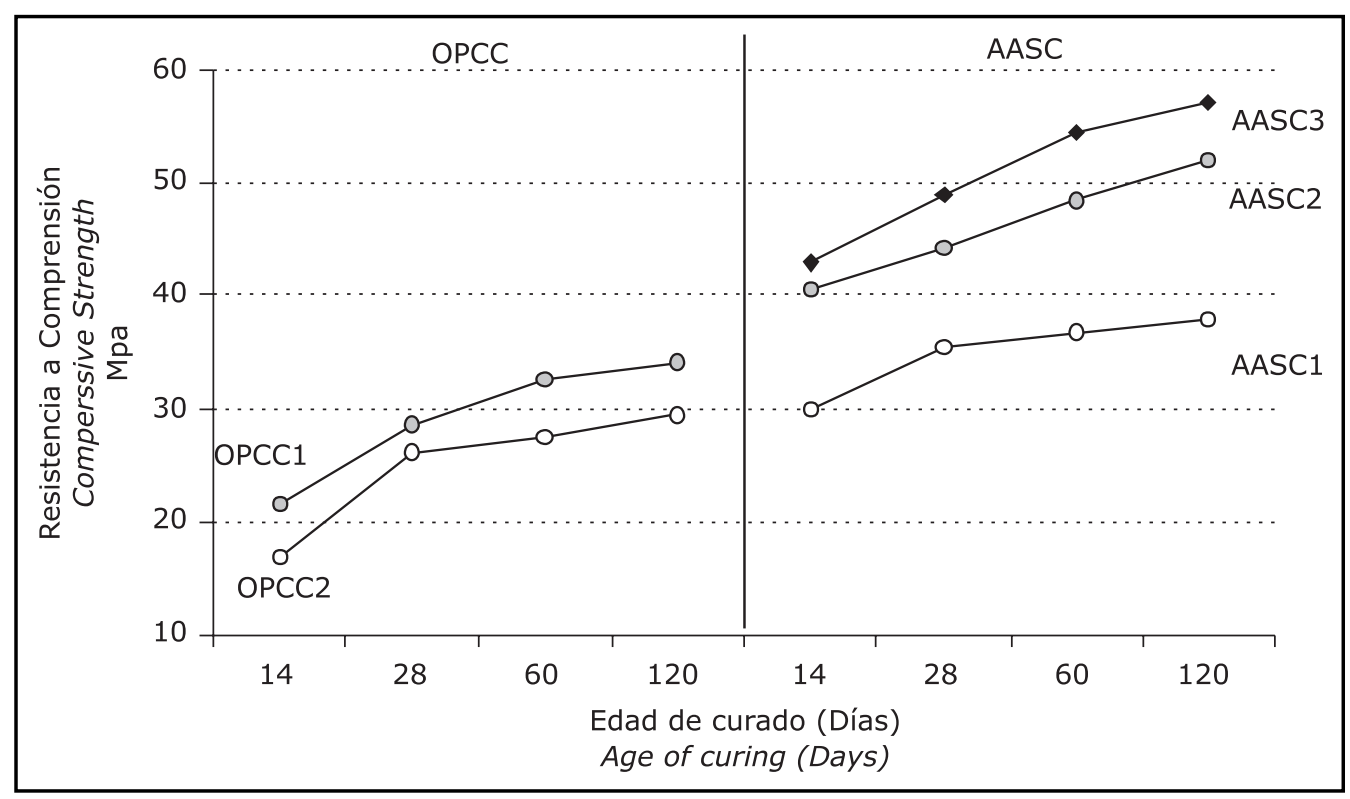

Figura 1. Resistencia a Compresión.

Figure 1. Compressive Strength.

Los índices de comportamiento para los hormigones activados, calculados en base a los resultados de resistencia obtenidos y la ecuación [1], presentaron un valor notoriamente superior a cortas edades de curado. Sin embargo, se observó una disminución de más del doble conforme se extendía la edad de curado, aunque los valores en todos los casos superan al hormigón de referencia. Un aumento del $20 \%$ en la dosificación de la cantidad de escoria $(410 \mathrm{~kg})$ genera índices superiores hasta en un $85 \%$. El efecto de la cantidad de cemento o escoria sobre la resistencia a la compresión de los hormigones es más marcada para los hormigones de AAS donde se obtienen diferencias de hasta un $37 \%$ (cuando las cantidades de ligante corresponden a $340 \mathrm{~kg}$ y $410 \mathrm{~kg}$ ), en contraste con un $28 \%$ para los OPC. No obstante, cuando la cantidad de escoria es un $50 \%$ superior $(512 \mathrm{~K}$ ) el incremento de la resistencia, comparado con la mezcla de AAS con $410 \mathrm{~kg}$, no resulto ser altamente significativo (11\%).
The performance indices for activated concrete calculated from the strength values obtained with equation [1] are visibly higher for the early ages. While these values declined by over half throughout the curing period, they were consistently higher than the figures for the control. A $20 \%$ increase in the slag dose $(410 \mathrm{~kg}$ ) raised the indices by up to $85 \%$. The amount of cement or slag had a greater effect on concrete compressive strength in AASC, with differences of up to $37 \%$ (for $410 \mathrm{~kg}$ compared to $340 \mathrm{~kg}$ ), than on OPC, where the difference was $28 \%$. When the slag dose was raised by $50 \%(512 \mathrm{~kg})$, however, the increase in strength over the values for $410 \mathrm{~kg}$ was not highly significant 11\%).

Tabla 4 / Table 4

Índice de comportamiento de los hormigones de AAS, \%

Performance index of AAS, \%

\begin{tabular}{|c|c|c|c|c|}
\hline \multirow[t]{2}{*}{ Mezcla / Mix } & \multicolumn{4}{|c|}{$\begin{array}{c}\text { Edad de Curado (Días) } \\
\text { Age of Curing (Days) }\end{array}$} \\
\hline & 14 & 28 & 60 & 120 \\
\hline AAS1 & 78.0 & 35.7 & 34.4 & 28.4 \\
\hline AAS2 & 88.8 & 55.1 & 49.4 & 52.1 \\
\hline
\end{tabular}

El buen comportamiento mecánico presentado por los hormigones de AAS se atribuye principalmente a que las
The high mechanical strength exhibited by AAS concrete is attributed primarily to the fact that the characteristic 
reacciones de hidratación características, tras la activación alcalina de la escoria, se rigen por fenómenos de disolución y precipitación, los cuales presentan una cinética de reacción mayor que las reacciones de difusión en la hidratación del cemento Portland (13-15). Las altas concentraciones de $\mathrm{OH}^{-}$en la solución de waterglass permiten la rotura de la estructura de la escoria (Ca-O; Si-O y el Al-O) (16), estas especies disueltas $\left(\mathrm{Ca}^{2+} ; \mathrm{H}_{2} \mathrm{SiO}_{4}\right]^{2-},\left[\mathrm{H}_{3} \mathrm{SiO}_{4}\right]^{-}$y $\left.\left[\mathrm{HAlO}_{4}\right]^{-}\right)^{4-}$ (17) pueden precipitar una vez alcanzado un valor máximo de concentración y generar la nucleación de aluminatos y silicatos disueltos en el entorno alcalino favoreciendo la formación de un hidrato de C-S-H $(5,17)$ (el cual se caracteriza por un bajo orden estructural debido a una baja relación $\mathrm{Ca} / \mathrm{Si}$ y presencia de unidades de Si de tipo Q3) (11). Por otra parte, la ausencia de portlandita $\left(\mathrm{Ca}(\mathrm{OH})_{2}\right)$ y ettringita $\left(\mathrm{AF}_{\mathrm{t}}\right)$ en la interfase matriz-árido, contribuyen a la mejora de la zona interfacial donde los álcalis aceleran la dispersión y reacción de sustancias arcillosas presentes en la superficie de los áridos (18).

\subsection{Absorción y porosidad total del hormigón endurecido}

De acuerdo al procedimiento planteado en la norma ASTM C642 se determinó el porcentaje de absorción y porosidad total de los especímenes de hormigón a 60 días de curado. Con base a los resultados obtenidos (Figura 2) y a los criterios de absorción (<3\%) y a la porosidad $(<10 \%)$ se puede afirmar que las mezclas de AAS, a todas las cantidades de escoria evaluadas, pueden catalogarse como materiales de elevada durabilidad. hydration reactions taking place after slag alkali activation are governed by dissolution and precipitation mechanisms, whose reaction kinetics are faster than the diffusion reactions that prevail in Portland cement hydration (13-15). The high $\mathrm{OH}^{-}$concentrations in the waterglass solution lead to the breakdown of the slag structure into $\mathrm{Ca}-\mathrm{O}, \mathrm{Si}-\mathrm{O}$ and $\mathrm{Al}-\mathrm{O}$. When these dissolved species (Ca2+; $\left[\mathrm{H}_{2} \mathrm{SiO}_{4}\right]^{2-},\left[\mathrm{H}_{3} \mathrm{SiO}_{4}\right]^{-}$and $\left.\left[\mathrm{HAlO}_{4}\right]^{-}\right)^{4-}(15)$ reach the maximum concentration they may precipitate, prompting the nucleation of the dissolved aluminates and silicates in an alkaline environment. This would favour the formation of a $\mathrm{C}-\mathrm{S}-\mathrm{H}$ gel $(5,17)$ characterized y short range order due to its low Ca/Si ratio and the presence of $Q^{3}$-type Si units (11). Moreover, the absence of portlandite $\left(\mathrm{Ca}(\mathrm{OH})_{2}\right)$ and ettringite $\left(A F_{t}\right)$ at the binder-aggregate interface contributes to better adherence, while the alkalis enhance the dispersion and reactivity of the clay substance present on the aggregate surface (18).

\subsection{Absorption and total porosity in the hardened concrete}

The absorption percentage and voids were determined with 60-day concrete specimens as laid down in ASTM standard C642. On the grounds of the results obtained (Figure 2) and the absorption ( $<3 \%$ ) and void ( $<10 \%)$ criteria, all the AAS mixes, regardless of the slag dose, were classified as durable materials.

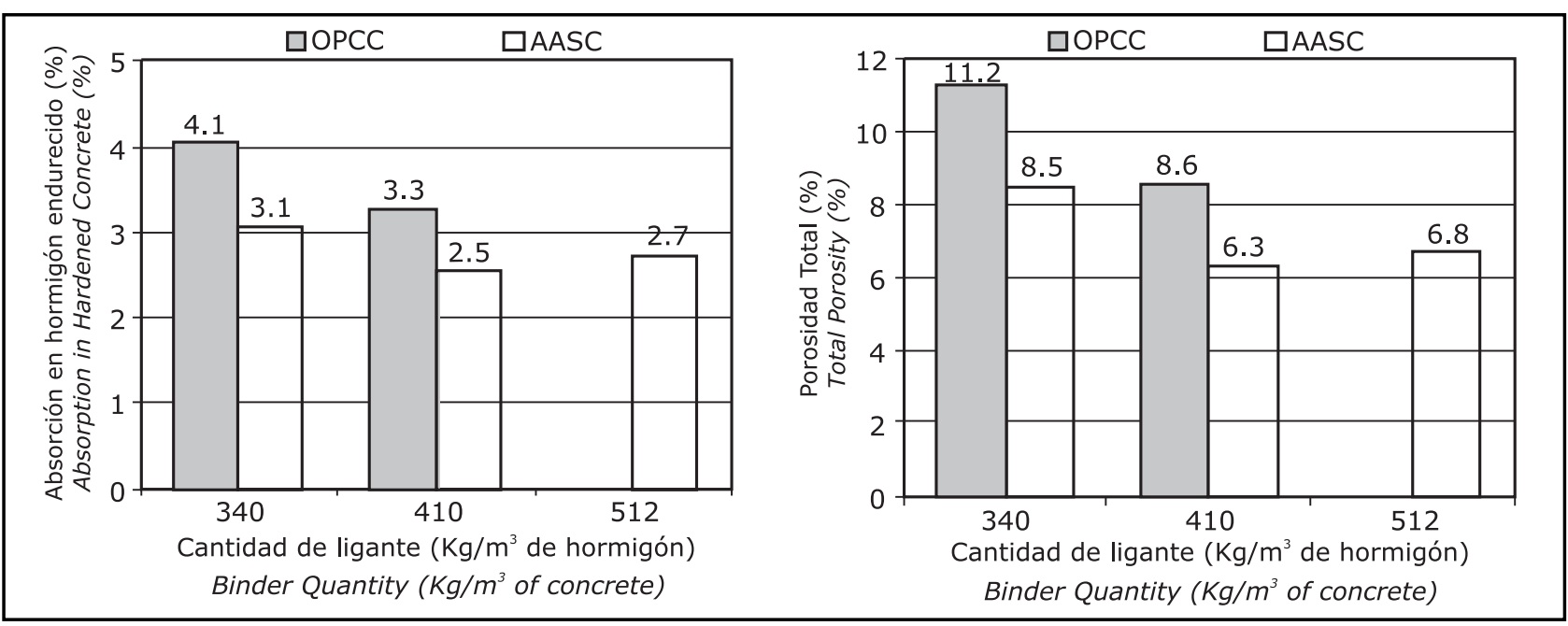

Figura 2. \% Absorción y porosidad total de los hormigones.

Figure 2. \% Total water absorption and porosity of concretes.

Cuando la dosificación del contenido de escoria en el diseño de la mezcla se incrementa en un $20 \%$ ( 410 $\mathrm{kg} / \mathrm{m}^{3}$ ) la porosidad puede disminuir hasta un $35 \%$, sin
When the slag dosage was increased by $20 \%$ (410 $\left.\mathrm{kg} / \mathrm{m}^{3}\right)$, the voids content declined by up to $35 \%$. When 
embargo, al incrementar la proporción de escoria a 512 $\mathrm{kg} / \mathrm{m}^{3}$ no se observa un efecto significativo en la reducción de la porosidad para estos materiales, comparado con las mezclas con cantidades inferiores de escoria.

\subsection{Capacidad de absorción capilar}

Para el ensayo de absorción capilar se tomaron muestras cilíndricas de $76 \mathrm{~mm}$ de diámetro y $50 \mathrm{~mm}$ de espesor con 60 días de curado, las cuales fueron previamente acondicionadas mediante la impermeabilización de sus caras laterales curvas y secado a $50{ }^{\circ} \mathrm{C}$ durante 48 horas. Se registró el cambio en peso por unidad de área expuesta bajo una superficie húmeda a diferentes intervalos de tiempo. Con base a los datos recogidos se calculó el coeficiente de absorción capilar (k) y la resistencia a la penetración de agua $(\mathrm{m})$, los cuales describen la cinética de absorción (12), estos resultados se presentan en la Figura 3. the proportion of slag was raised to $512 \mathrm{~kg} / \mathrm{m}^{3}$, however, no significant reduction of porosity was observed over mixes with smaller doses of slag.

\subsection{Capillary absorption}

Cylindrical 60-day specimens $76 \mathrm{~mm}$ in diameter and 50 $\mathrm{mm}$ high were dried at $50^{\circ} \mathrm{C}$ for 48 hours. After the curved sides were waterproofed for the capillary absorbability test, a moist surface was set on top the samples, which were weighed at different time intervals. The weights recorded were then used to calculate two absorption kinetics parameters, the capillary suction coefficient $(k)$ and water permeability $(m)(12)$; the results are shown in Figure 3.

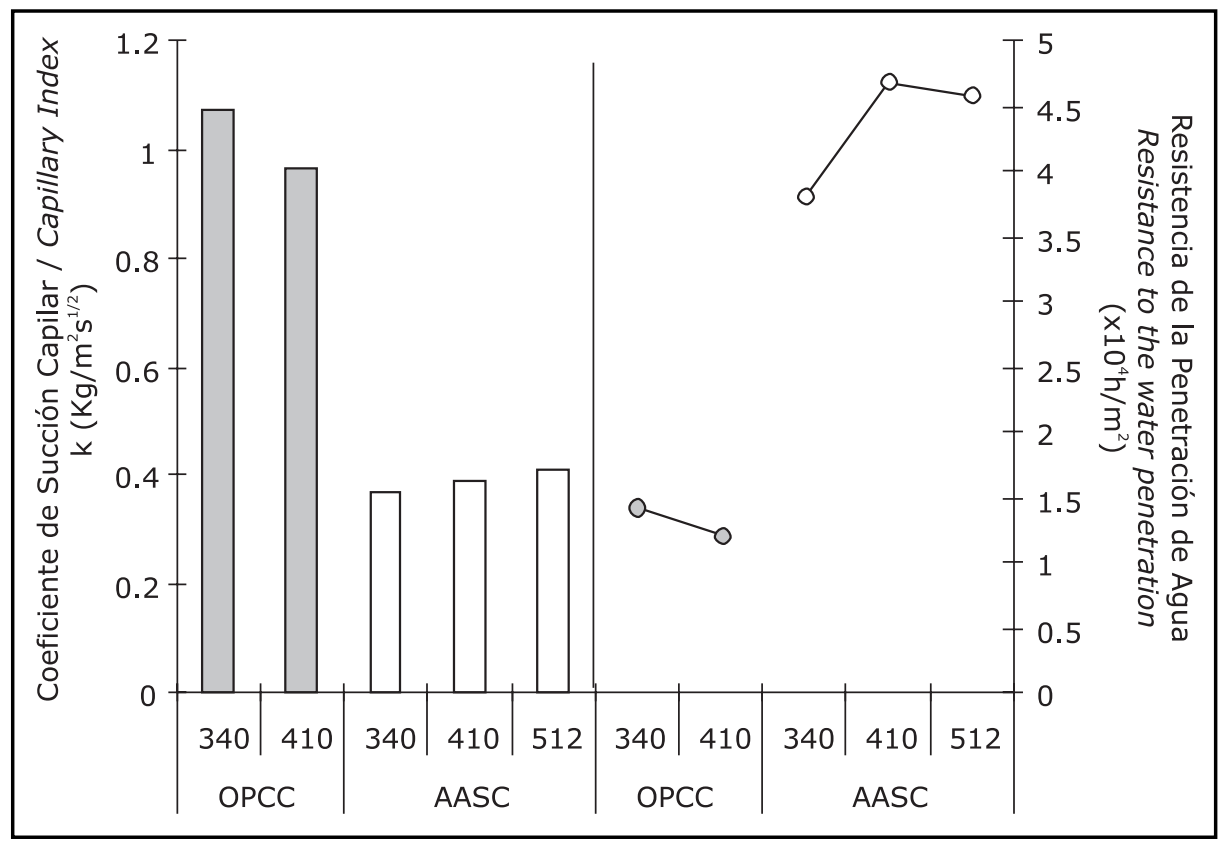

Figura 3. Absorción Capilar (k) y Resistencia a la Penetración de Agua (m).

Figure 3. Capillary absorption index $(k)$ and water penetration resistance $(m)$.

Los coeficientes de succión capilar ( $k$ ) para los hormigones de AAS son aproximadamente 2,8 veces menores que los valores encontrados para los OPC e igualmente los datos de resistencia a la penetración de agua $(\mathrm{m})$ muestran resultados muy superiores a los de OPC, lo cual indica que los hormigones de AAS poseen una permeabilidad significativamente menor frente a los hormigones referencia, esto es indicativo de su carácter de materiales mas densos y resistentes. Con incrementos en la cantidad de cementante $\left(410 \mathrm{~kg} / \mathrm{m}^{3}\right)$ se obtiene un incremento en la resistencia a la penetración de agua de un
The capillary suction coefficients $(k)$ for AAS concrete were approximately 2.8 times lower than the OPCC values. The water permeability data $(m)$ likewise showed that the AASC performed better than the OPC materials, indicating that the AAS concrete was significantly less permeable than the control, a reflection, in turn, of its higher density and strength. Raising the cementitious material (to $410 \mathrm{~kg} / \mathrm{m}^{3}$ ) led to $23 \%$ greater resistance to water penetration. This confirms the high slag reactivity in the presence of alkaline activators, for the hydration 
$23 \%$. Se confirma así, la excelente reactividad de la escoria en presencia de los activadores alcalinos al generar productos de hidratación que contribuyen al refinamiento de poros y densificación del hormigón (19-20).

\subsection{Resistencia a la penetración del ión cloruro}

Se determinó la resistencia a la penetración del ion cloruro sobre especimenes cilíndricos de $76 \mathrm{~mm}$ de diámetro y 50 $\mathrm{mm}$ de espesor con 60 días de curado. Se aplicó una diferencia de potencial de $60 \mathrm{~V}$ durante 6 horas con base en los procedimientos de la norma ASTM C1202 para el cálculo de la carga total transferida (en Coulombs). A su vez se determinó la resistividad que ofrece el material con base a los valores de corriente inicial y a las dimensiones del especimen. Los valores obtenidos se muestran en la Figura 4, en la cual se puede apreciar una diferencia de hasta 1.650 Culombios entre los hormigones de OPC y AAS con cantidades de ligante equivalentes; de igual forma la resistividad de los hormigones activados es aproximadamente 2 veces mayor que la presentada por los hormigones de referencia. Estos resultados son coherentes con las resistencias mecánicas y los valores de porosidad obtenidos. products generated must have contributed to enhancing concrete pore refinement and density (19-20).

\subsection{Chloride ion resistance}

Chloride ion resistance was determined on 60-day cylindrical specimens measuring $76 \mathrm{~mm}$ in diameter and 50 $\mathrm{mm}$ high. A 60-V potential difference was applied for 6 hours to calculate the total charge passed according to ASTM standard C1202. Material resistivity was also determined, based on the initial current values and specimen dimensions. The readings are shown in Figure 4 , where a difference of up to 1,650 coulombs was observed between OPC and AAS concretes with equivalent amounts of cementitious material; the resistivity in the activated concrete proved to be approximately twice as high as in the control. These findings are consistent with the mechanical strength and voids content results.

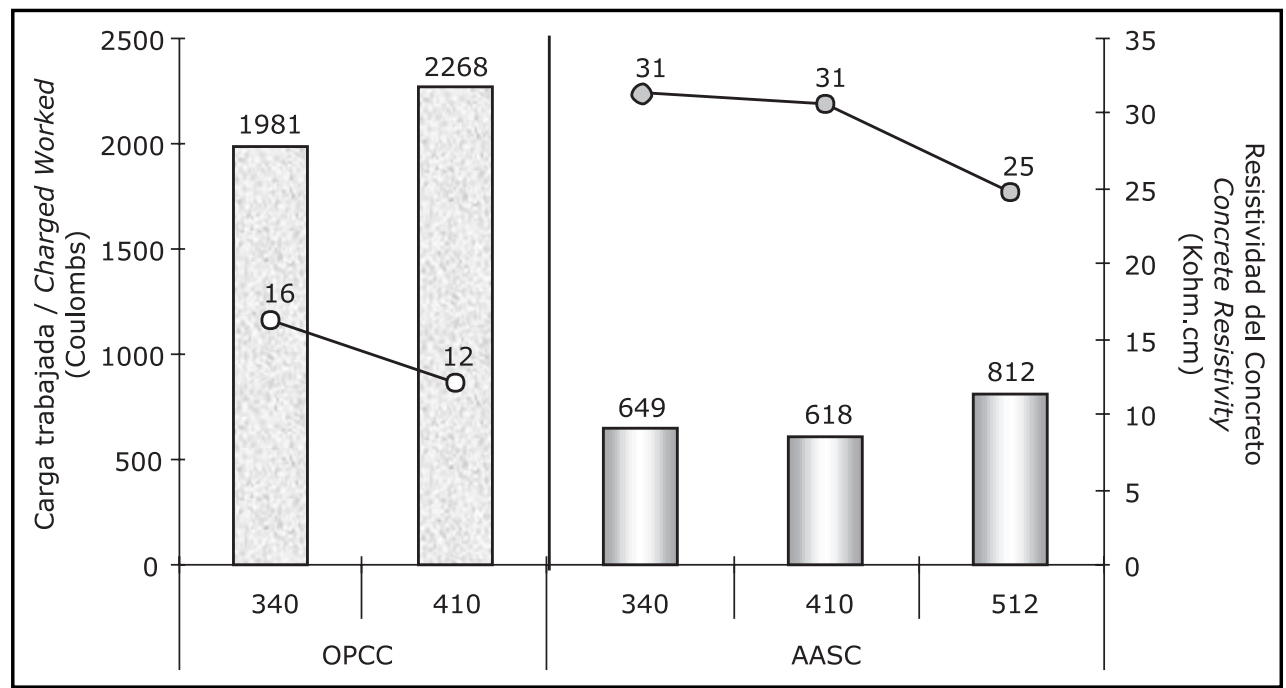

Figura 4. Permeabilidad a cloruros y resistividad de los hormigones.

Figure 4. Chloride permeability and resistivity value of concretes.

En general los hormigones de AAS, independientemente de contenido de escoria en la mezcla, presentan valores de permeabilidad muy bajos (ASTM C1202). Los resultados obtenidos están en concordancia a lo reportado por otros investigadores (21).

\subsection{Comportamiento frente a sulfatos}

Especímenes de hormigón con 60 días de curado fueron colocados en inmersión completa en una solución de sul-
The AAS concretes exhibited very low permeability (ASTM C1202), regardless of the proportion of slag in the mix. These findings concur with the results reported by other researchers (21).

\subsection{Sulphate resistance}

Sixty-day concrete specimens were completely submerged in a $5 \%$ sodium sulphate solution $\left(\mathrm{Na}_{2} \mathrm{SO}_{4}\right)$ for 90 
fato de sodio $\left(\mathrm{Na}_{2} \mathrm{SO}_{4}\right)$ al $5 \%$ por un intervalo de 90 días (ASTM C1012). En la Tabla 5 se presenta el porcentaje de expansión de las probetas y el cambio en la resistencia a compresión por efecto del ataque de la disolución (Índice de pérdida de resistencia). Como resultado de la exposición, la matriz de cemento Portland sufre un mayor deterioro atribuible a la formación de yeso $\left(\mathrm{CSH}_{2}\right)$ y etringita $\left(\mathrm{C}_{6} \mathrm{AS}_{3} \mathrm{H}_{32}\right)$, especies expansivas. Por el contrario, los hormigones de AAS presentan una mayor resistencia frente a este tipo de medio debido a la ausencia de aluminato tricálcico $\left(\mathrm{C}_{3} \mathrm{~A}\right)$ y mayor contenido de productos de hidratación más estables e insolubles (como el C-S-H), así como la retracción que presentan, la cual es posible que compense parte de la expansión (19). days (ASTM C1012). Specimen expansion, expressed in per cent, and the variations in compressive strength after exposure to the solution (strength loss index) are given in Table 5. The Portland cement specimens underwent more severe deterioration in the presence of sulphates than the AAS materials due to the formation of gypsum $\left(\mathrm{CSH}_{2}\right)$ and ettringite $\left(\mathrm{C}_{6} A S_{3} \mathrm{H}_{32}\right)$, both of which are expansive species. AAS concretes were more resistant to this type of medium due to the absence of tricalcium aluminate $\left(C_{3} A\right)$ and the higher concentration of more stable insoluble hydration products (such as $\mathrm{C}-\mathrm{S}-\mathrm{H}$ ) in these concretes. Shrinkage may also have partially offset expansion (19).

Tabla 5 / Table 5

Resultados de exposición a sulfatos

Sulfate exposition results

\begin{tabular}{|c|c|c|c|}
\hline $\begin{array}{c}\text { Mezcla / } \\
\text { Mix }\end{array}$ & $\begin{array}{c}\text { Cantidad Ligante } \\
\text { Binder Quantity } \\
{\left[\mathbf{k g} / \mathbf{m}^{\mathbf{3}}\right]}\end{array}$ & $\begin{array}{c}\text { Expansión } \\
\text { Expansion } \\
\mathbf{( \% )}\end{array}$ & $\begin{array}{c}\text { Índice de Resistencia } \\
\text { Strength Index }\end{array}$ \\
\hline \multirow{2}{*}{ OPCC } & 340 & 0.564 & 0.74 \\
\hline \multirow{3}{*}{ AASC } & 410 & 0.679 & 0.67 \\
\cline { 2 - 4 } & 340 & 0.139 & 0.96 \\
\cline { 2 - 4 } & 410 & 0.099 & 0.98 \\
\hline
\end{tabular}

Los resultados encontrados en el presente estudio demuestran la superioridad de los hormigones activados, cuyos porcentajes de expansión calculados fueron seis veces menores que los encontrados para los hormigones de referencia, a su vez, este ultimo, registró perdidas de resistencia de hasta un $43 \%$, comportamiento opuesto a los AAS donde los valores de resistencia permanecieron aproximadamente equivalentes frente a especímenes que no fueron inmersos. Por otra parte, el incremento en la cantidad de escoria en los hormigones de AAS no modifica significativamente el comportamiento frente a sulfatos. Los resultados encontrados por parte de los hormigones activados con waterglass son coherentes con los resultados obtenidos por otros investigadores, los cuales destacan la resistencia de este tipo de materiales frente al ataque químico del ion sulfato (22-24) y, a su vez, concuerdan con resultados previos obtenidos en morteros (25).

\subsection{Comportamiento frente a la carbonatación}

El comportamiento frente a la carbonatación de los hormigones en estudio se evaluó en una cámara climática de $\mathrm{CO}_{2}$, por medio de la exposición de los especimenes durante un periodo de hasta 16 días a una concentración de $\mathrm{CO}_{2}$ del $7 \% \pm 0,5$, a una temperatura de $30^{\circ} \pm 1^{\circ} \mathrm{C}$ y una humedad relativa del $70 \pm 3 \%$ (Figura 5). Probetas cilíndricas de $76 \mathrm{~mm}$ de diámetro con 60 días de curado
According to the present findings, the activated concretes exhibited higher performance, with expansion percentages six times smaller than in the control. Moreover, while strength losses of up to $43 \%$ were recorded for the latter, in the AAS specimens strength remained essentially unchanged after immersion. Nor did raising the amount of slag in AAS concretes have any significant effect on sulphate resistance. The findings for concretes activated with waterglass were consistent with the results obtained by other researchers, who reported high sulphate resistance values for this type of materials (22-24); they concurred as well with the performance observed in prior research on mortars (25).

\subsection{Carbonation resistance}

The behaviour of the concretes studied when exposed to carbonation was assessed in a $\mathrm{CO}_{2}$ chamber, where the specimens were stored for up to 16 days at $\mathrm{CO}_{2}$ concentrations of $7 \pm 0.5 \%$ at a temperature of $30 \pm 1{ }^{\circ} \mathrm{C}$ and a relative humidity of $70 \pm 3 \%$ (Figure 5). Cylindrical 60-day specimens measuring $76 \mathrm{~mm}$ in diameter and $50 \mathrm{~mm}$ 
fueron impermeabilizadas por las caras laterales planas para direccionar el ingreso del agente agresivo. high were waterproofed on the sides to predetermine the direction of penetration of the aggressive agent.

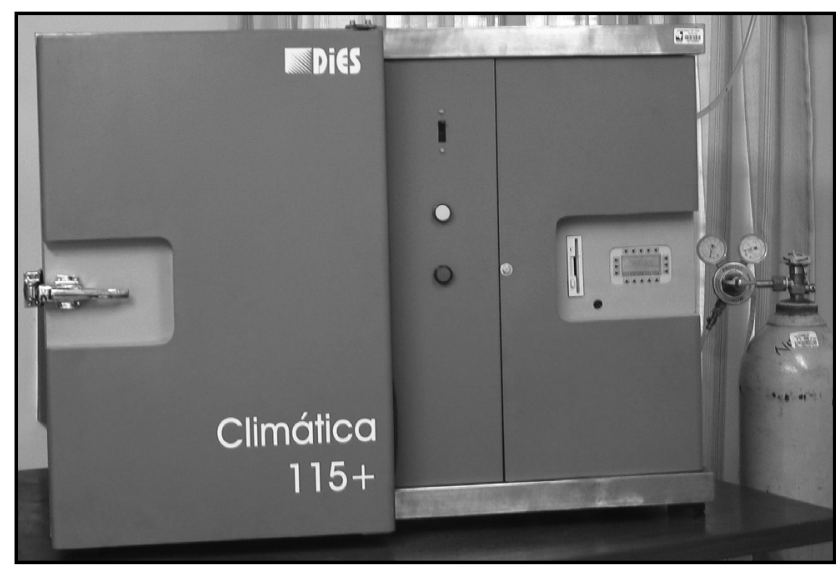

Figura 5. Cámara climática de $\mathrm{CO}_{2}$.

Figure 5. Climatic chamber of $\mathrm{CO}_{2}$.

El avance del frente de carbonatación fue determinado mediante la aspersión de una disolución alcohólica de fenoftaleina al $1 \%$ sobre muestras cortadas transversalmente expuestas bajo las condiciones del ensayo durante 240 y 384 horas. Este indicador muestra el cambio de $\mathrm{pH}$ por efecto de la reacción de $\mathrm{CO}_{2}$ con los productos de hidratación de las pastas, correspondiendo la región de color violeta a aquella superficie donde el $\mathrm{pH}$ es mayor a 9, es decir, la zona de no carbonatación. Los datos presentados en este trabajo corresponden al promedio de cuatro mediciones realizadas radialmente. Tomando en consideración que la velocidad de carbonatación es un proceso que puede ser descrito como función del tiempo se ha utilizado para el cálculo del coeficiente de carbonatación la expresión indicada en la ecuación [2].
After exposure to the test conditions for 240 and 380 hours, carbonation front progression was determined by sprinkling discs cut from the samples with a $1 \%$ phenolphthalein solution. This indicator reveals changes in $\mathrm{pH}$ caused by the reaction between $\mathrm{CO}_{2}$ and the hydration products in pastes. $A$ violet colour denotes a $\mathrm{pH}$ of over 9; i.e., non-carbonated areas. The data shown constitute the mean of four radial measurements. Inasmuch as the carbonation rate can be described in terms of time, the expression in equation [2] below was used to calculate the carbonation coefficient.

$$
K_{c}=\frac{x}{\sqrt{t}}
$$

donde Kc corresponde al coeficiente de carbonatación (mm/año1/2) $x$ a la distancia del frente de carbonatación (mm) y $\mathrm{t}$ al tiempo de exposición (años) (26-29). Los datos obtenidos y calculados de acuerdo a la ecuación [2] para las diferentes mezclas y edades de exposición en estudio se muestran en la Figura 6, junto con la fotografía de los especímenes revelados una vez fueron expuestos durante 384 horas.

Los hormigones de AAS presentaron una mayor susceptibilidad a la carbonatación, donde se observó un frente tres veces superior a los encontrados en los OPC. De igual forma, los coeficientes de carbonatación calculados para los hormigones de AAS indican la susceptibilidad de este material a la carbonatación. Sin embargo, para ambos materiales (AAS y OPC), el incremento en la can- where $K c$ is the carbonation coefficient $\left(m m /\right.$ year $\left.^{1 / 2}\right), x$ is the width of the carbonation front $(\mathrm{mm})$ and $t$ the exposure time (years) (26-29). The data collected and calculated equation [2] for the different mixes and exposure ages are shown in Figure 6, together with photographs of 384-hour specimens after application of the phenolphthalein solution.

The AAS concretes proved to be more vulnerable to carbonation, with a front three times wider than found in the OPCS. Similarly, the carbonation coefficients calculated for the AAS concretes denoted their susceptibility to carbonation. In both the AAS and OPC concretes, however, an increase in the amount of cementitious material reduced $\mathrm{CO}_{2}$ penetration in the concrete and prevented the 


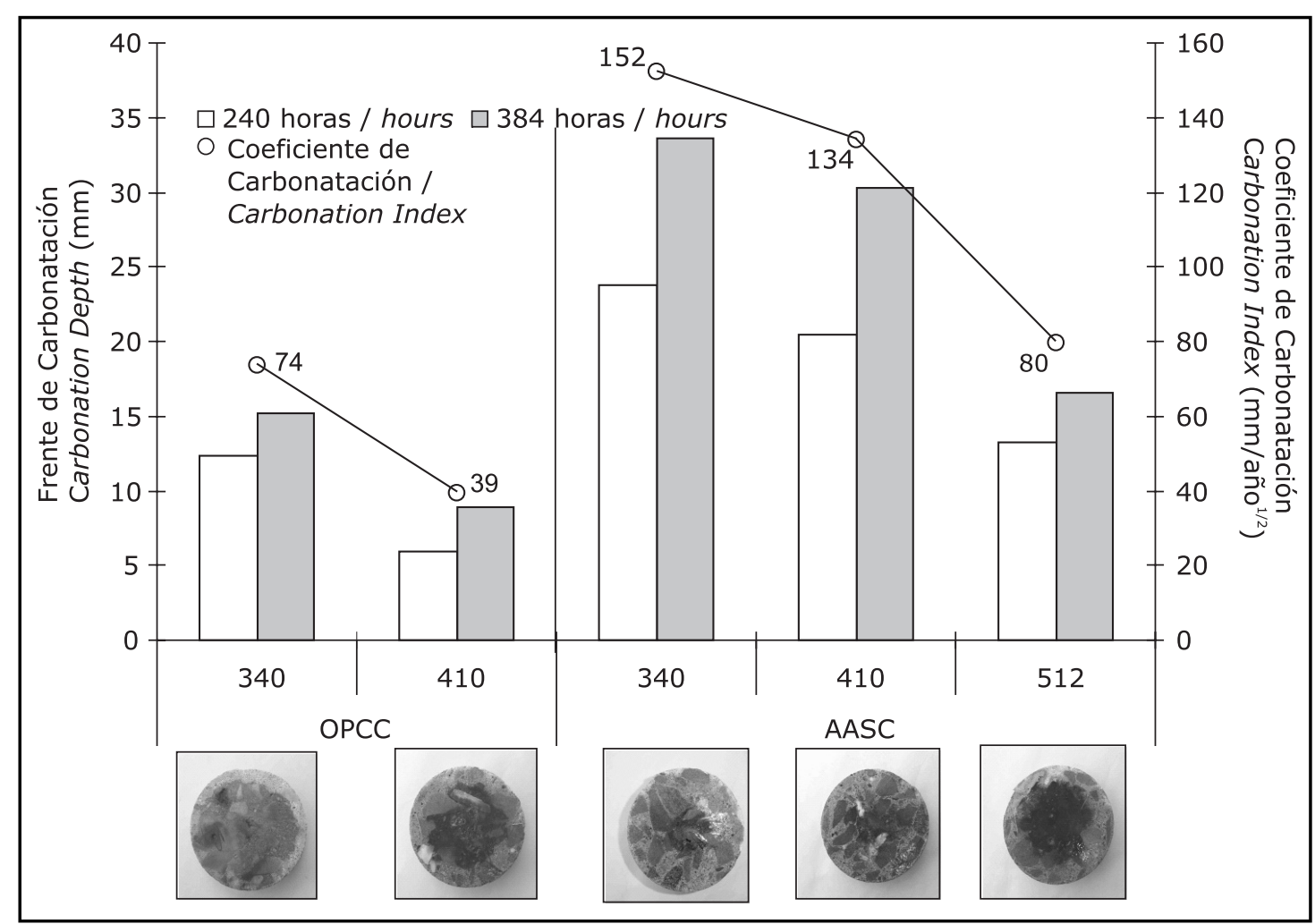

Figura 6. Ensayo de carbonatación acelerada.

Figure 6. Accelerated carbonation test.

tidad de Ligante reduce el ingreso del $\mathrm{CO}_{2}$ hacia el interior del hormigón y con ello el cambio de $\mathrm{pH}$ en la solución del poro. Así, el incremento en un $20 \%$ en la cantidad de material ligante $\left(410 \mathrm{~kg} / \mathrm{m}^{3}\right)$ para los hormigones de OPC y AAS reduce el frente de carbonatación hasta en un $100 \%$ y $16 \%$, respectivamente. Este comportamiento está relacionado con los resultados de resistencia a compresión y porosidad de los hormigones, que demostraron que a mayor cantidad de cemento Portland y escoria en las mezclas de hormigón, obtenían materiales más densos y resistentes.

Simultáneamente se calculó el cambio en la resistencia a compresión sobre especímenes cúbicos de $50 \mathrm{~mm}$ expuestos al ensayo de carbonatación acelerada durante 384 horas frente a muestras que no fueron sometidas a atmósfera de $\mathrm{CO}_{2}$; los resultados obtenidos se presentan en la Tabla 6.

Se observa en la Tabla 6, que los hormigones de AAS presentan una pérdida de resistencia considerablemente mayor a la presentada por los OPC, revelando que la inclusión del $\mathrm{CO}_{2}$ hacia el interior del material modifica los productos de hidratación presentes en la pasta. No obstante, los resultados encontrados parecen ser contradictorios, debido a que los hormigones activados alcalinamente al no presentar fases de $\mathrm{Ca}(\mathrm{OH})_{2}$ deberían presen- lowering of the $\mathrm{pH}$ in the pore solution. A rise of $20 \%$ in the amount of cementitious material, for instance (410 $\mathrm{kg})$, narrowed the carbonation front in OPC and AAS by $100 \%$ and $16 \%$, respectively. Such behaviour was corroborated by the compressive strength and voids findings, according to which, the larger the dose of Portland cement or slag in the mixes, the denser and stronger were the concretes obtained.

Compressive strength was also calculated for $50-\mathrm{mm}$ cubic specimens exposed to accelerated carbonation for 384 hours and compared to the results for samples not subjected to a $\mathrm{CO}_{2}$ atmosphere; the findings and variation in per cent are given in Table 6.

Table 6 shows that strength loss was considerably greater in $A A S$ than $O P C$, an indication that $\mathrm{CO}_{2}$ penetration inside the material modified the hydration products present in the paste. These findings appear to be contradictory, however, for the alkali-activated concretes, which lack $\mathrm{Ca}(\mathrm{OH})_{2}$ phases, should be more resistant to carbonation than Portland cement concrete, whose high portlandite content would react with atmospheric $\mathrm{CO}_{2}$ to 
Tabla 6 / Table 6

Cambio en la resistencia mecánica (RC) por efecto de la carbonatación

Shift of compressive strength (CS) by effect of carbonation

\begin{tabular}{|c|c|c|c|c|}
\hline $\begin{array}{c}\text { Mezcla } \\
\text { Mix }\end{array}$ & $\begin{array}{c}\text { Ligante } \\
\text { Binder } \\
\left(\mathbf{K g} / \mathbf{m}^{\mathbf{3}}\right)\end{array}$ & $\begin{array}{c}\text { RC antes de carbonatación } \\
\text { CS before carbonation test } \\
\mathbf{( M P a )}\end{array}$ & $\begin{array}{c}\text { RC despues carbonatación } \\
\text { CS after carbonation test } \\
\mathbf{( M P a )}\end{array}$ & $\begin{array}{c}\text { Cambio en RC por efecto de la } \\
\text { carbonatación } \\
\text { Shift of CS by carbonation effect } \\
\mathbf{( \% )}\end{array}$ \\
\hline \multirow{2}{*}{ OPCC } & 340 & 31 & 27 & -14 \\
\cline { 2 - 5 } & 410 & 39 & 46 & 18 \\
\hline \multirow{2}{*}{ AASC } & 340 & 37 & 23 & -37 \\
\cline { 2 - 5 } & 410 & 47 & 26 & -44 \\
\hline
\end{tabular}

tar una mayor resistencia frente a la carbonatación en comparación a los hormigones de cemento Portland donde la cantidad de portlandita es alta, y el $\mathrm{CO}_{2}$ proveniente del medio reacciona con ésta para la formación de calcita $\left(\mathrm{CaCO}_{3}\right)$. Aquí debe anotarse, que investigaciones realizadas por diferentes investigadores $(20,30-33)$ han demostrando que el $\mathrm{CO}_{2}$ actúa en estos materiales directamente sobre el principal producto de su hidratación, el gel C-S-H generando su descalcificación y con ello una pérdida de cohesión de la matriz. Lo anterior, se corrobora al identificar en las mezclas carbonatadas un gel enriquecido en sílice y carbonato calcico (33). Se sugiere que este problema puede ser reducido si la finura de la escoria es incrementada significativamente (34) y los sistemas de curado se hacen mas eficientes (sistemas herméticos con una humedad relativa promedio del $90 \%$ ) (35).

\section{CONCLUSIONES}

Con base en los resultados obtenidos en el presente estudio se demuestra que los hormigones de escoria activados alcalinamente con una disolución de waterglass tienen un comportamiento mecánico y una durabilidad superior en comparación con hormigones tradicionales de cemento Portland, con iguales dosificaciones en mezcla. Simultáneamente, de manera general la incorporación de una cantidad adicional de material ligante en las mezclas de hormigón mejora sus propiedades mecánicas y densifica las estructuras disminuyendo la susceptibilidad al ingreso de agentes agresivos.

Los resultados de la evaluación de la resistencia a la carbonatación demostraron la susceptibilidad que presentan los hormigones activados para reaccionar con el $\mathrm{CO}_{2}$ y asociado a ello la disminución en sus propiedades mecánicas, sin embargo, esta aparente desventaja puede ser reducida con un incremento en la cantidad de ligante, de manera tal que es posible obtener comportamientos similares a los presentados por los hormigones de OPC. Cabe anotar que los estudios se hicieron con contenidos bas- form calcite $\left(\mathrm{CaCO}_{3}\right)$. Research conducted by several authors (20,30-33) has shown that in these materials $\mathrm{CO}_{2}$ reacts with the main hydration product, the $\mathrm{C}-\mathrm{S}-\mathrm{H}$ gel, directly, leading to its decalcification and a loss of cohesion in the matrix.The existence of silica-enriched gel and calcium carbonate in the mixes corroborated that premise (33). Some researchers have suggested that this problem could be attenuated by grinding the slag much more finely (34) and enhancing the efficiency of curing systems (air-tight systems with a mean relative humidity of around 90\%) (35).

\section{CONCLUSIONS}

The findings of the present study show that waterglassactivated slag concrete exhibits higher mechanical strength and durability than equivalently dosed traditional Portland cement concrete. Also, the inclusion of an additional amount of cementitious material in concrete mixes improves their mechanical properties and increases structural density, lowering their susceptibility to penetration by aggressive agents in both concretes, OPC and AAS.

The carbonation resistance findings showed that activated concrete is susceptible to reacting with $\mathrm{CO}_{2}$, which would lead to a decline in its mechanical strength. When the amount of cementitious material is increased, however, this apparent drawback is partially corrected, raising performance nearly to OPC levels. Inasmuch as the stu- 
tante elevados de $\mathrm{CO}_{2}$, es importante por tanto realizar estudios en condiciones normales de exposición para precisar en grado más alto este comportamiento.

\section{AGRADECIMIENTOS}

Los autores quieren agradecer a la Universidad del Valle (Colombia), al Instituto Colombiano para el Desarrollo de la Ciencia y la Tecnología "Francisco José de Caldas" (COLCIENCIAS), al Instituto de Ciencias de la Construcción Eduardo Torroja IETcc (CSIC - España) y al Centro de Excelencia en Nuevos Materiales (CENM) por el apoyo en el desarrollo de este estudio. dies were conducted with a fairly high $\mathrm{CO}_{2}$ content, studies under normal exposure conditions would be needed to measure performance more precisely.

\section{ACKNOWLEDGEMENTS}

The authors would want to express their gratitude for the support in the present stufy to the Universidad del Valle, Colombia, Institute for Scientific and Technological Development of Colombia (COLCIENCIAS), Eduardo Torroja Institute for Construction Science (IETCC) and the Center of Excellence in Novel Materials (CENM).

\section{BIBLIOGRAFIA / BIBLIOGRAPHY}

(1) Hardjito, D., Rangan, B. V.: "Development and properties of low-calcium fly ash-bases geopolymer concrete". Research Report GC1. Curtin University of Technology. Perth Australia (2005).

(2) Hendriks, C. A., et al.: "Emission reduction of green house gases from the cement industry". 4th International Conference on Green House Gas Control Technologies, Intertaken, Austria (1998).

(3) Glukovski, V.D.: "Alkali-Earth binders and concretes produced with them", Visheka Shkola, Kiev, USSR (1979).

(4) Fernández-Jimenez, A, Puertas, F.: "Effect of activator mix on the hydration and strenght behavior of alkali-activated slags cements". Advances In Cements Research, vol. 15 (2003), pp.129-136. http://dx.doi.org/10.1680/adcr.15.3.129.36623

(5) Fernández Jiménez, A, Puertas, F.: "Setting of alkali-activated slag cement. Influence of activator nature". Advances In Cement Research, vol 13, 3 (2001), pp.115-121.

(6) Bakharev, T., Sanjayan, J. G., Cheng, Y. B.: "Effect of admixtures on properties of alkali-activated slag concrete". Cement And Concrete Research, vol 30 (2000), pp.1367-1374. http://dx.doi.org/10.1016/S0008-8846(00)00349-5

(7) Puertas F., Palomo A., Fernández-Jiménez A. y Izquierdo J. D.: "Effect of superplasticizers on the behaviour and properties of alkaline cements" Advance Cement Research, vol 15, 1 (2003), pp. 23-28.

(8) Puertas, F., Gil-Maroto, A., Palacios, M., Arvert, T.: "Alkali-activated slag mortars reinforced with a glass fibre. Performance and properties". Mater. Construcc. vol 56, no 283, 79-90 (2006).

(9) Alcaide, J. S., Alcocel, E. Ga., Puertas, F., Lafuente, R., García, P.: "Carbon fibre-reinforced alkali-activated slag mortars". Mater. Construcc., vol 57, no 288, 33-48 (2007).

(10) Palacios M. y Puertas F.: "Effect of superplasticizer and shrinkage-reducing admixtures on álcali-activated slag pastes and mortars". Cement and Concrete Research, vol. 35 (2005), pp. 1358-1367. http://dx.doi.org/10.1016/j.cemconres.2004.10.014

(11) Puertas, F., Fernández-Jiménez, A., Blanco-Varela, M.T.: "Pore solution in alkali-activated slag cement pastes. Relation to the composition and structure of calcium silicate hydrate". Cement and Concrete Research, vol. 34 (2004), pp. 139-148 http://dx.doi.org/10.1016/ S0008-8846(03)00254-0

(12) Fagerlund, G.: "On the capillarity of concrete". Nordic Concrete Research № 1, Oslo, Paper № 6 (1982), 20 p.

(13) Roy, D.M.: "Advances in cements/Chemically Bonded Ceramics, Ceramics Toward The 21 St Century". Centennial International Symposium, Ceramics Society Of Japan, Tokyo, 535-551 (1991).

(14) Wang, S-D., Scrivener, K.: "Hydration products of alkali activated slag cement". Cement and Concrete Research, vol 25, 3 (1995), pp. 561-571.

(15) Roy, D.M., Silsbee, M.R.: "Alkali activated materials. An overview", Mat. Res. Soc., Symp. Proc. 245, pp.153-164, (1992).

(16) Teoreanu, I.. "The interaction mechanism of blast-furnace slags with water. The role of the activating agents". Il Cemento 2, pp. 9197 (1991).

(17) Shi, C.: "Early hydration and microstructure development of alkaliactivated slag cement pastes", $X$ Intern. Cong. Chem, Cem (Goteborg) Vol. 3, 3ii099, Trondheim, Norwa, (1997).

(18) Wang S-D., Pu, Xin-Cheng, Scrivener, K.L. y Pratt, P .L.: "Alkali activated slag cement and concrete: a review of its properties and problems". Advances in Cement Research, vol 24 (1995), pp. 93-102.

(19) Mejía De Gutiérrez, R., Maldonado, J., Delvasto, S., Puertas, F. y Fernández-Jiménez, A.: "Durability of mortars made with alkali activated slag". 11th Int. Congress on the Chemistry of Cement, ICCC, Durban, South Africa 1005-1012. (2003).

(20) Mejía De Gutiérrez, R., Angrino, D., Maldonado, J., Delvasto, S., Puertas, F. y Fernandez-Jimenez, A.: "Durability properties of ordinary, slag blended and alkali - activated slag cement mortars". International Corrosion Council, Granada Spain, 575 (2002).

(21) Byfors, K., et al.: "Durability of concrete made with alkali-activated slag, 3rd International Conference on Fly Ash, Silica -fume, Slag and Natural Pozzolans in concrete". V.M. Malhotra (Ed.), Norway, 1429-1466 (1989). 
(22) Kukko, H., Mannonen, R.: "Chemical and mechanical properties of alkali-activated blast furnace slag (F-Concrete)", Nordic Concrete Research, Pub No 10510 (1982).

(23) Puertas, F.: "Cementos de escoria activados alcalinamente: Situación actual y perspectivas de futuro". Mater. Construcc., vol 45 (239) (1995), pp. 53-64.

(24) Bakharev, T., Sanjayan, J.G.y Cheng, Y-B.: "Sulfate attack on alkali-activated slag concrete". Cement and Concrete Research, vol 32, (2002), pp. 211-216. doi:10.1016/S0008-8846(01)00659-7

(25) F. Puertas, R. M. Gutiérrez, A. Fernández-Jiménez, S. Delvasto y J. Maldonado.: "Alkaline cement mortars. Chemical resistance to sulfate and sea water attack". Mater. Construcc., vol 51, 267 (2002) pp. 55-71.

(26) Linares, D. y Sánchez, M.: "Construction operation and preformance of a chamber of test of accelerated carbonation". Rev. Tec. Univ. Zulia, vol 26, 1 (2003), pp. 34-44.

(27) Steffens, A.: "Modeling carbonation for corrosion risk prediction of concrete structures". Cement and Concrete Research, vol 32, (2002), pp. 935-941. http://dx.doi.org/10.1016/S0008-8846(02)00728-7

(28) Castro, A. et al.: "Relationship between results of accelerated and natural Carbonation in various Concretes". International RILEM conference on the use of recycled materials in buildings and structures, Barcelona, España, 988-997 (2004).

(29) Mejía De Gutiérrez, R, Rodríguez, E, Rodríguez, C, Torres, J. y Delvasto, S.: "Comportamiento frente a la corrosión de concretos adicionados con metacaolín de origen nacional". I Coloquio de Investigaciones en Materiales no Convencionales Brasil - Colombia. Cali, 114 (2005).

(30) Pu, X. C., Gan, C. C., Wang, S. D. y Yang, C. H.: "Summary reports of research on alkali-activated slag cement and concrete". V.16, Chongqing Institute of Architecture and Engineering, Chongqing, (1988).

(31) Bakharev, T., Sanjayan, J. G. y Cheng, Y. B.: "Resistence of alkali-activated slag concrete to carbonation". Cement and Concrete Research, vol 31 (2001), pp. 1277-1283. http://dx.doi.org/10.1016/S0008-8846(01)00574-9

(32) Puertas, F., Palacios, M., Vázquez, T.: "Carbonation process of alkali-activated slag". Journal of Material Science, vol. 41, n 10, 3071$3082(2006)$.

(33) Palacios, M., Puertas, F.: "Effect of carbonation on alkali-activated slag parter". Journal of American Ceramic Society, 88 (10), 3211 3221 (2006).

(34) Zhang, X, Wu, K.y Yan, A.: "Carbonation property of hardened binder pastes containing super-pulverized blast-furnace slag". Cement and Concrete Composites, vol 26 (2004). pp. 371-374. http://dx.doi.org/10.1016/S0958-9465(03)00021-0

(35) Criado, M., Palomo, A. Y Fernández-Jiménez, A.: "Alkali activation of fly ashes. Part 1: Effect of curing conditions on the carbonation of the reaction products", Fuel, vol 84 (2005). pp. 2048-2054. http://dx.doi.org/10.1016/j.fuel.2005.03.030 